\title{
Kejadian Ikutan Pasca Imunisasi Antigen Vi Polisakarida Kapsular
}

\author{
Hartono Gunardi, Soedjatmiko, Rini Sekartini, Jeane Roos Ticoalu
}

\begin{abstract}
Demam tifoid masih merupakan masalah kesehatan masyarakat. Upaya pencegahan meliputi perbaikan sanitasi lingkungan, higiene perorangan, persiapan makanan yang baik dan pemberian vaksin. Baik vaksin tifoid peroral maupun parenteral dapat mencegah gejala klinis demam tifoid. Kejadian ikutan pasca imunisasi (KIPI) vaksin antigen Vi polisakarida kapsuler pada anak Indonesia belum banyak dilaporkan. Penelitian ini bertujuan untuk mengetahui KIPI vaksin antigen Vi polisakarida kapsuler pada anak Indonesia.

Metode. Penelitian deskriptif potong-lintang dilakukan pada anak Indonesia sehat umur 2-5 tahun yang mengunjungi Klinik Tumbuh Kembang Utan Kayu pada Juli 2000 atau Klinik Dokter Keluarga Kiara pada Agustus 2000. Digunakan vaksin antigen Vi polisakarida kapsuler (typhim-Vi) dalam kemasan $10 \mathrm{ml}$. Penyuntikan $0,5 \mathrm{ml}$ vaksin dilakukan oleh dokter Peserta Pendidikan Spesialis Anak pada paha bagian anterolateral dengan menggunakan semprit steril sekali pakai. KIPI dimonitor dengan menggunakan formulir KIPI Departemen Kesehatan.

Hasil. Dari 198 anak yang divaksinasi, KIPI yang berhasil dipantau 174 (87,9\%) anak. Gejala klinis KIPI yang ditemukan adalah nyeri pada tempat suntikan $(44,8 \%)$, demam $>38,5 \infty \mathrm{C}(14,4 \%)$, indurasi $(9,2 \%)$, dan muntah $(0,6 \%)$.

Kesimpulan. KIPI vaksin antigen Vi polisakarida kapsuler penelitian ini cukup komparabel dengan penelitian lain dalam hal demam. Bengkak dan indurasi lebih tinggi dibanding penelitian lain. Hal yang mungkin berperan adalah vial multidosis yang rentan terhadap timbulnya kontaminasi.
\end{abstract}

Kata kunci: KIPI, imunisasi tifoid parental.

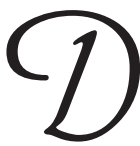

Demam tifoid masih menjadi masalah kesehatan masyarakat karena penyakit ini masih bersifat endemis. Prevalensi demam tifoid di Indonesia diperkirakan 350-810

Kepala Subbagian Tumbuh Kembang Pediatri Sosial. Bagian Ilmu Kesehatan Anak FKUI-RSCM. Jakarta (Dr. Soedjatmiko, Sp.A.), Staf Subbagian Tumbuh Kembang Pediatri Sosial. Bagian Ilmu Kesehatan Anak FKUI-RSCM. Jakarta (Dr. Rini Sekartini, Sp.A.) dan PPDS Bagian Ilmu Kesehatan Anak FKUI-RSCM. Jakarta (Dr. Jeane Roos Ticoalu, Sp.A.).

Alamat korespondensi:

Dr. Hartono Gunardi, Sp.A.

Staf Subbagian Tumbuh Kembang Pediatri Sosial. Bagian Ilmu Kesehatan Anak FKUI-RSCM. Jl. Salemba No. 6. Jakarta 10430.

Telepon 021-316 0622. Fax. 021-390 7743. kasus per 100.000 penduduk per tahun atau kurang lebih sekitar 600 ribu sampai 1, 5 juta kasus setiap tahunnya. ${ }^{1}$ Di Bagian Ilmu Kesehatan Anak FKUIRSCM pada tahun 1990- 1994 tercatat 578 kasus demam tifoid. ${ }^{2}$ Pada Bagian Ilmu Kesehatan Anak RS Dr Sutomo pada tahun 1984-1988 terdapat kasus demam tifoid sebanyak 143, 137, 102, 237 dan 241 per tahun dengan angka kematian antara $0,7-2,15 \% .^{3}$

Dalam beberapa tahun terakhir, terdapat laporan di beberapa negara mengenai adanya kasus demam tifoid anak yang berat bahkan fatal dan ternyata disebabkan oleh galur Salmonella typhi yang telah resisten terhadap 2 atau lebih jenis antibiotik yang lazim digunakan untuk pengobatan demam tifoid. ${ }^{4}$ Walaupun galur tersebut belum dijumpai di Bagian 
IKA FKUI-RSCM ${ }^{5}$, aspek pencegahan tetap merupakan upaya yang terbaik untuk mengurangi morbiditas maupun mortalitas demam tifoid.

Demam tifoid berkaitan erat dengan kesehatan lingkungan maupun higiene perorangan yang kurang terutama di negara sedang berkembang. Upaya pencegahan perlu dilakukan melalui perbaikan sanitasi pembuangan, kebersihan perorangan, kebersihan makanan maupun penggunaan vaksin.

Vaksin tifoid oral maupun parenteral diharapkan dapat menurunkan angka kejadian demam tifoid pada anak. Salah satu vaksin tifoid parenteral adalah vaksin antigen Vi polisakarida kapsular yang diberikan secara intramuskular pada anak usia di atas 2 tahun, dan diulang dilakukan setiap 3 tahun.

Kejadian ikutan pasca imunisasi vaksin antigen $\mathrm{Vi}$ polisakarida kapsular pada anak Indonesia belum dilaporkan pada kepustakaan Indonesia. Penelitian KIPI yang telah dipublikasi adalah pada bayi 6-12 bulan. ${ }^{6}$ Tujuan penelitian ini adalah untuk mengetahui kejadian ikutan pasca imunisasi antigen $\mathrm{Vi}$ polisakarida kapsular pada anak Indonesia.

\section{Metodologi}

Penelitian kejadian ikutan pasca imunisasi bersifat deskriptif - potong lintang (cross sectional). Subjek penelitian adalah anak sehat usia 2 tahun ke atas. Penelitian dilakukan di Klinik Tumbuh Kembang Utan Kayu pada bulan Juli 2000 dan pada Klinik Dokter Keluarga Kiara pada bulan Agustus 2000. Vaksin yang digunakan adalah antigen Vi polisakarida kapsular multidose $10 \mathrm{ml}$ (hospital packed) diproduksi oleh Pasteur Merieux (Typhim Vi,). Semprit yang digunakan adalah semprit 2,5 $\mathrm{ml}$ merk Terumo. Tindakan a dan antiseptik dilakukan dengan kapas alkohol $70 \%$ kemasan sekali pakai Vaksin disuntik intramuskular sebanyak $0,5 \mathrm{ml}$ di daerah anterolateral femoral kanan atau kiri. Penyuntikan dilakukan oleh dokter peserta pendidikan spesialis anak FKUI-RSCM. Setelah itu dilakukan pemantauan kejadian ikutan pasca imunisasi oleh dokter yang sama, berdasarkan anamnesis ibu atau pengantar anak sewaktu kunjungan tindak lanjut dengan menggunakan formulir KIPI Departemen Kesehatan RI (Lampiran 1). KIPI yang dipantau adalah demam tinggi $\left(>38,5^{\circ} \mathrm{C}\right)$, pingsan, muntah, diare, kejang, bengkak pada tempat suntikan, pembesaran kelenjar, kesadaran menurun, pucat, lemas, menggigil, kebiruan atau sianosis. Pemantauan dilakukan selama 2 minggu setelah imunisasi.

\section{Hasil}

Subjek penelitian 198 anak, namun yang berhasil dipantau 174 anak dengan rincian tertera pada Gambar 1.

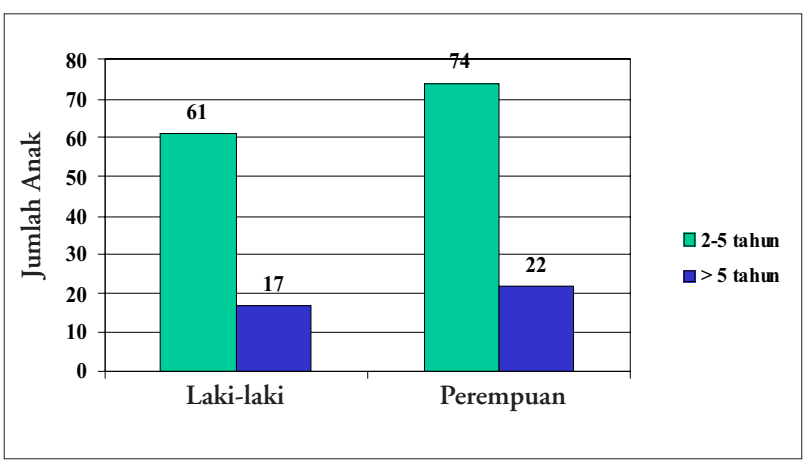

Gambar 1. Distribusi kelompok umur dan jenis kelamin anak yang mendapat antigen Vi polisakarida kapsular dan pemantauan KIPI

Kejadian ikutan pasca imunisasi yang terbanyak ditemukan yaitu nyeri pada tempat suntikan 78 $(44,8 \%)$ anak, demam tinggi $>38,5^{\circ} \mathrm{C}$ terdapat pada $25(14,4 \%)$ anak, indurasi pada $16(9,2 \%)$ anak. Satu anak mengalami muntah $(0,6 \%)$, sedangkan 54 anak lainnya tidak mempunyai keluhan (31\%). Gejala KIPI, onset dan lama gejala selengkapnya tercantum pada Tabel 1. Pada anak yang mengalami kejadian ikutan pasca imunisasi diberikan pengobatan simtomatis.

\section{Diskusi}

Imunisasi yang memadai dan mempunyai efikasi yang baik akan sangat membantu pembasmian demam tifoid di samping mengendalikan faktor risiko lainnya. ${ }^{2}$ Faktor risiko yang mempermudah tertularnya anak dengan kuman Salmonela antara lain usia di bawah

Tabel 1. KIPI antigen Vi polisakarida kapsular pada 174 anak sehat

\begin{tabular}{llcc}
\hline KIPI & $\%^{*}$ & Onset (jam) & Lama (jam) \\
& & & \\
Demam $>38,5^{\circ} \mathrm{C}$ & 14,4 & 4 & 6 \\
Demam $<38,5^{\circ} \mathrm{C}$ & 14,9 & 4 & 3 \\
Indurasi & 9,2 & 4 & 13 \\
Nyeri lokal & 44,8 & 4 & 6 \\
Muntah & 0,6 & 24 & 1 \\
\hline
\end{tabular}

* satu anak dapat menderita lebih dari satu KIPI

**median 
Sari Pediatri, Vol. 3, No. 3, Desember 2001

Table 2. Penelitian KIPI vaksin tifoid antigen $\mathrm{Vi}^{10}$

\begin{tabular}{lllllll}
\hline Penelitian & $\begin{array}{l}\text { Rentang } \\
\text { range } \\
\text { (umur) }\end{array}$ & $\begin{array}{l}\text { Jenis } \\
\text { penelitian }\end{array}$ & $\begin{array}{l}\text { Jumlah } \\
\text { subjek yg } \\
\text { divaksinasi }\end{array}$ & $\begin{array}{l}\text { Demam } \\
(\%)\end{array}$ & $\begin{array}{l}\text { Bengkak } \\
(\%)\end{array}$ & $\begin{array}{l}\text { Muntah } \\
(\%)\end{array}$ \\
\hline $\begin{array}{l}\text { Levin et al } \\
\text { Tacket et al }\end{array}$ & ND & Klinis & 21 & 24 & ND & NA \\
Klugman et al & $5-15$ & Klinis & 19 & 0 & ND & NA \\
Cumberland et al & $18-22$ & Klinis & 388 & $<1$ & 4 & NA \\
Mirza et al & $5-15$ & Komunitas & 435 & 0 & 8 & NA \\
Pooled estimate & & & & $1.1(0.1$ to & $3.7(1.3$ to & \\
(95\% CI) & & & & $12.3)$ & $9.6)$ &
\end{tabular}

$\mathrm{NA}=$ tak ada data

ND = tidak dijelaskan dalam penelitian

Sumber : Engels EA., dkk,. ${ }^{10}$

lima tahun, gangguan motilitas usus, aklorhidria, pemakaian antasida rutin. ${ }^{7}$

Efikasi vaksin antigen Vi polisakarida kapsuler dalam penelitian di Nepal yang melibatkan 6907 peserta adalah $75 \% .{ }^{8}$ Adapun kejadian ikutan pasca imunisasi berupa reaksi minor menurut Plotkin ${ }^{9}$ kurang dari $10 \%$. Vaksinasi dengan suntikan antigen Vi polisakarida kapsuler telah diuji pada anak Indonesia dengan efikasi yang baik dan daya lindung yang baik pada bayi 6-12 bulan. ${ }^{6}$

Pada penelitian ini kejadian ikutan pasca imunisasi antigen $\mathrm{Vi}$ polisakarida kapsular yang dijumpai agak berbeda dengan penelitian lain, yaitu yang terbanyak adalah nyeri pada tempat suntikan, dan demam. Frekuensi demam pada penelitian ini lebih rendah dibanding penelitian Levine $\mathrm{dkk}$, tetapi lebih tinggi dibanding penelitian lain. Adapun bengkak ataupun indurasi pada penelitian ini lebih tinggi dibandingkan penelitian lain ${ }^{8}$ (lihat Tabel 2).

Penyebab tingginya demam mungkin disebabkan oleh penggunaan vaksin multidose. Meskipun tindakan a dan antiseptik telah dijalankan, kontaminasi dengan zat pirogen agaknya sulit dihindarkan pada penelitian ini. Beruntung bahwa sebagian besar KIPI berlangsung 13 jam saja dan seluruhnya hilang dalam 48 jam.

\section{Kesimpulan}

Vaksin antigen Vi polisakarida kapsular merupakan vaksin tifoid yang aman diberikan pada anak Indonesia usia 2 tahun ke atas, dengan kejadian ikutan pasca imunisasi yang relatif ringan.

\section{Daftar Pustaka}

1. Simanjuntak CH. Masalah demam tifoid di Indonesia. Cermin Dunia Kedokteran 1990; 60:31-4.

2. Tumbelaka AR. Masalah demam tifoid pada anak. Mimeograf.

3. Atasiati Idajadi, Setio Harsono, Mertaniasih NM. Problems and studies on Salmonellosis. Dalam Nelwan RHH, penyunting. Typhoid fever, profile, diagnosis and treatment in the 1990's. Dipresentasikan pada $1^{\text {st }}$ ISAC International treatment Symposium. Jakarta: FKUI Press, 1992. h. 157-62.

4. Bhuta ZAA, Khan IA, Molla AM. Therapy of multidrugresistant typhoid fever with oral cefixim vs intravenous cetriaxone. Pediatr Infect Dis J 1994; 13:990-4.

5. Hadinegoro SR. Masalah multidrug resistance pada demam tifoid anak. Siang klinik: Pandangan baru pengobatan demam tifoid. Jakarta 26 Agustus 1998.

6. Simanjuntak $\mathrm{CH}$, Punjabi NH, Hartatiningsih, Faisal ET, Pusponegoro T, Basri HH dkk. Side effects and immune respons of a parenteral Vi-CPS vaccine in Indonesian infants aged 6-12 months. Dipresentasikan pada Simposium Perkembangan baru dalam Diagnostik dan pencegahan (imunisasi) Demam Tifoid. Jakarta: Perhimpunan Peneliti Penyakit Tropik dan Infeksi Indonesia (PETRI), 1995.

7. Committee on Infectious Disease American Academy of Pediatrics. 2000 Red Book: Report of the Committee on Infectious Disease. American Academy of Pediatrics: Elk Grove Village 2000.

8. Acharya I. Prevention of typhoid fever in Nepal with the Vi capsular polysaccharide of Salmonella typhi. A preliminary report. N. Engl J Med 1987; 317:1101-4.

9. Plotkin SA, Bouveret-Le Cam N. A new typhoid vaccine composed of the Vi capsular polysaccharide. Arch Intern Med 1995; 155:2293-9 (abstrak).

10. Engels EA., Falagas ME., Lau J., Bennish ML. Typhoid fever vaccines: a metaanalysis of studies on efficacy and toxicity. BMJ 1998; 316:110-6. 


\section{Lampiran}

Formulir Pemantauan Kejadian Ikutan Pasca Imunisasi

\begin{tabular}{|l|l|l|}
\hline \multicolumn{1}{|c|}{ Identitas pasien } & & Peneliti \\
\hline Nama : & Tgl lahir: & \\
\hline & Umur : th bl & \\
\hline Alamat : & Kelamin : L / P & Lokasi: \\
\hline & & $\square$ Poli IKA RSCM \\
\hline Kota : & BB : $\quad$ kg & $\square$ Poli Utan Kayu \\
\hline & PB : cm & $\square$ Lain: \\
\hline Telepon: & LK : cm & \\
\hline
\end{tabular}

\begin{tabular}{|l|l|l|}
\hline \multicolumn{1}{|c|}{ Penyuntikan vaksin } & Tgl : & Lokasi injeksi \\
\hline Jenis & Penyuntik: & \\
\hline No Lot/Batch: & Dr/Ns & \\
\hline
\end{tabular}

\begin{tabular}{|l|l|l|}
\hline Kejadian Ikutan Pasca Imunisasi & Saat timbul & Lama gejala (jam) \\
\hline$\square$ Reaksi alergi & & \\
\hline$\square$ Demam tinggi $\left(>38,5^{\circ}\right)$ & & \\
\hline$\square$ Pingsan & & \\
\hline$\square$ Muntah & & \\
\hline$\square$ Diare & & \\
\hline Kejang & & \\
\hline$\square$ Bengkak pada tempat suntikan & & \\
\hline$\square$ Pembesaran kelenjar ...................... & & \\
\hline$\square$ Kesadaran menurun & & \\
\hline$\square$ Pucat & & \\
\hline$\square$ Lemas & & \\
\hline$\square$ Menggigil & & \\
\hline$\square$ Kebiruan / sianosis & & \\
\hline$\square$ Menangis terus menerus selama 3 jam & & \\
\hline$\square$ Lain-lain : & & \\
\hline
\end{tabular}

\begin{tabular}{|lll|}
\hline Tindakan yang dilakukan & Keadaan akhir & KIPI mungkin disebabkan oleh \\
\hline Rawat jalan & $\square$ Sembuh & $\square$ vaksin secara langsung \\
\hline$\square$ Rawat inap & $\square$ Gejala sisa: & $\square$ diperberat oleh vaksin \\
\hline$\square$ Lain-lain: & & $\square$ kesalahan teknis penyuntikan \\
\hline Terapi: & Diagnosis akhir: & $\square$ koinsidens dengan imunisasi \\
\hline
\end{tabular}

